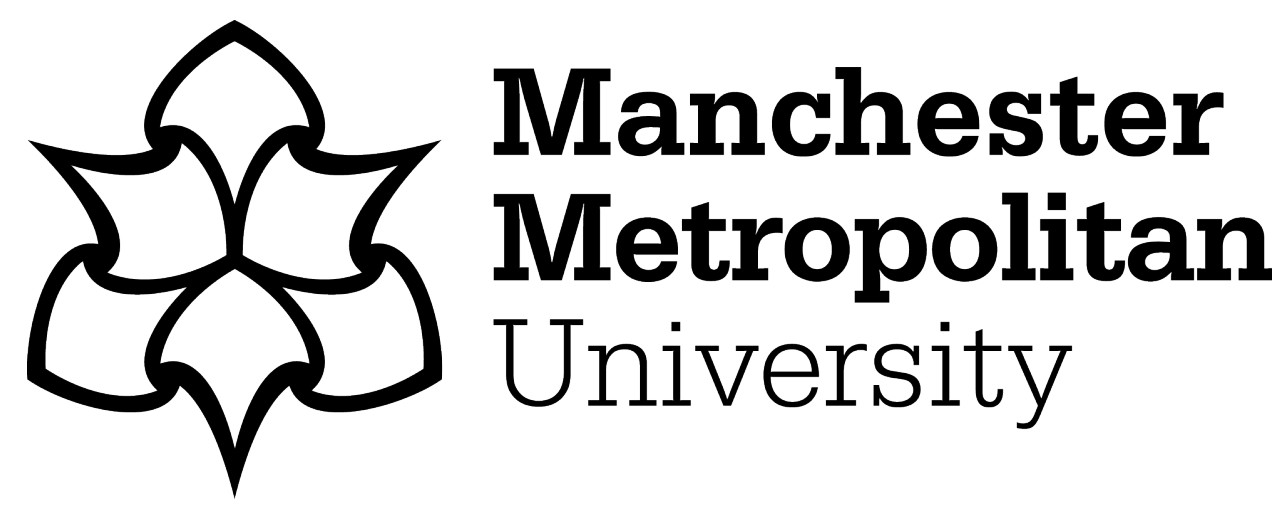

Saini, Rakesh, Sharma, Milap Chand, Deswal, Sanjay, Barr, lestyn David ORCID logoORCID: https://orcid.org/0000-0002-9066-8738, Kumar, Pawan, Kumar, Parvendra, Kumar, Pankaj and Chopra, Sundeep (2019) Glacioarchaeological evidence of permanent settlements within a glacier end moraine complex during 980-1840 AD: The Miyar Basin, Lahaul Himalaya, India. Anthropocene, 26. p. 100197. ISSN 2213-3054

Downloaded from: https://e-space.mmu.ac.uk/622734/

Version: Accepted Version

Publisher: Elsevier BV

DOI: https://doi.org/10.1016/j.ancene.2019.100197

Usage rights: Creative Commons: Attribution-Noncommercial-No Derivative Works 4.0

Please cite the published version 


\title{
Glacio-archaeological evidence of permanent settlements within a glacier end moraine complex during 980-1840 AD: The Miyar Basin, Lahaul Himalaya, India
}

\author{
Rakesh Saini ${ }^{\mathrm{a}, *}$, Milap Chand Sharma ${ }^{\mathrm{b}}$, Sanjay Deswal ${ }^{\mathrm{c}}$, Iestyn David Barr ${ }^{\mathrm{d}}$, \\ Pawan Kumar ${ }^{\mathrm{b}}$, Parvendra Kumar ${ }^{\mathrm{a}}$, Pankaj Kumar ${ }^{\mathrm{e}}$, Sundeep Chopra ${ }^{\mathrm{e}}$ \\ a Department of General \& Applied Geography, Dr. Harisingh Gour Central University, Sagar, 470003, India \\ b Centre for the Study of Regional Development, Jawaharlal Nehru University, New Delhi, 110067, India \\ ${ }^{\mathrm{c}}$ Department of Geography, Govt College Dujana, Dujana, India \\ ' School of Science and Environment, Manchester Metropolitan University, Manchester, United Kingdom \\ e Inter University Accelerator Centre (IUAC), New Delhi, 110067, India
}

A R T I C L E I N F O

Article history:

Received 3 September 2018

Received in revised form 15 February 2019

Accepted 21 February 2019

Available online 22 February 2019

Keywords:

Glacio-archaeology

Little Ice Age

Glacier fluctuations

Lahaul Himalaya

\begin{abstract}
A B S T R A C T
This study presents glacio-archaeological evidence from the Miyar basin, Lahaul Himalaya, that points towards the former presence of a well settled agricultural society, within a glacier end moraine complex. Three high altitude villages (Tharang, Phundang and Patam, now in ruins) with elaborate irrigation networks thrived within the end moraine complex of Tharang glacier at $3700 \mathrm{~m}$ a.s.l. Evidence exists in the form of dilapidated houses which had an organised internal space, chronologically constrained by radiocarbon $\left({ }^{14} \mathrm{C}\right)$ dating. These settlements occupied the end moraine complex between 980 and 1840 CE, thereby encompassing the majority of Little Ice Age period (1300-1600 CE), as defined elsewhere. The existence of settlements along with an irrigation system and associate fields at $\sim 3700-3800 \mathrm{~m}$ a.s.l. for almost $\sim 860$ years during the late $10^{\text {th }}$ to early $19^{\text {th }}$ centuries suggests more favourable climatic (warm) conditions that at present. By contrast, present habitation is restricted to areas below $\sim 3500 \mathrm{~m}$ a.s.l. However, the slope controlled irrigation system also suggests moisture stressed conditions during the 980-1840 CE period, similar to present. The available temperature and snowfall proxies for the region support our proposed timing, and suggest favourable climatic conditions for the survival of these settlements.
\end{abstract}

(C) 2019 Elsevier Ltd. All rights reserved.

\section{Introduction}

The Himalaya contains the largest concentration of glaciers outside the polar regions, and are a source of water for $\sim 800$ million people (Bolch et al., 2012). Glacier fluctuations in the region can result in hazards and associated water shortage issues (Richardson and Reynolds, 2000). Understanding these glacier fluctuations during the last two millennia, including the Medieval Warm Period (800-1300 CE) and the Little Ice Age (LIA: 1300-1600 CE), will help us to understand present day climate variability, and predict future conditions (Nesje and Dahl, 2003). Prior to work by Mayewski and Jeschke, (1979), little was known about glacier fluctuations in the Himalaya over the last two millennia. However, in the last three decades, many studies have helped in revealing the glacial history of

\footnotetext{
* Corresponding author.

E-mail address: rakesh83jnu@hotmail.com (R. Saini).
}

this region. Rowan (2016); Solomina et al.(2016), and Xu and Yi (2014) summarise the glacial chronology and thereby constrain the timing, extent and frequency of glacier fluctuations. Studies from neighbouring regions suggest one (Sharma and Owen, 1996; Barnard et al., 2004a; Deswal et al., 2017) or two (Owen et al., 1996,1997, 2001; Taylor and Mitchell, 2000; Barnard et al., 2004b; Orr et al., 2018, 2017) episodes of glacier advance during the LIA period. In terms of the timing, studies suggest glacier expansion at $\sim 800$ years BP and $\sim 200$ years BP in the Upper Chandrabhaga basin and Zanskar (Owen et al., 1996, 1997, 2001; Taylor and Mitchell, 2000; Orr et al., 2017, 2018); during 200-300 years BP in NW Garhwal (Sharma and Owen, 1996; Barnard et al., 2004a); during 600-140 years BP in the Gori Ganga basin (Barnard et al., 2004b); and at 150 years BP in the Miyar Basin (current study area) (Deswal et al., 2017). These glacier fluctuations were dated based on sediments within terminal moraines, located $\sim 1-2 \mathrm{~km}$ from contemporary glaciers. Other studies also suggest LIA glacier expansion in the Himalaya, but are mostly based on relative rather than absolute chronologies (Owen et al., 1996, 1998, 2000, 
2001, 2002a, 2002b, 2005; Sharma and Owen, 1996; Derbishyre and Owen, 1997; Lehmkuhl et al., 1998; Taylor and Mitchell, 2000; Spencer and Owen, 2004). In the Himalaya, wherever numerical dating has been applied, there are typically a limited number of dates ( $\leq 2$ ) (Iwata, 1976; Richards et al., 2000; Owen et al., 2001). Areas which have been historically accessible, such as Khumbu (Fushimi, 1978; Iwata, 1976; Richards et al., 2000), Garhwal (Barnard et al., 2004a; Murari et al., 2014), Milam (Barnard et al., 2004b), and Gonga Shan (Owen et al., 2005) have produced most dates. In brief, most of the glacial chronology of the region is based on the Central Himalaya (Khumbu and Garhwal Himalaya), and often dictated by the accessibility of particular well-dated or well-studied sites. Owen (2009) highlights the limited accessibility and paucity of suitable material to date recent glacial fluctuations in the region.

Despite these limitations, attempts have been made to understand glacial fluctuations in the region by analysing climatic proxies, such as tree rings (Singh and Yadav, 2005; Yadav, 2011a, 2011b, 2013), lake and lacustrine sediment geochemistry (Juyal et al., 2009; Phartiyal et al., 2009; Wunnemann etal., 2010; Srivastava et al., 2013; Mishra et al., 2014; Bali et al., 2017), and speleothems (Sinha et al., 2011; Sanwal et al., 2013; Liang et al., 2015). However, findings from these proxies are often contradictory, for example suggesting weaker (Gupta et al., 2003; Sinha et al., 2011; Yadav, 2011b) as well as stronger monsoon (Liang et al., 2015) conditions during the LIA, and sometimes suggesting glacier expansion during this period, and sometimes not. As a result, there is clearly a need for additional research, based on a robust chronology, in order to improve undemanding of LIA glacier fluctuations in this region.
Glacial archaeology and historical records (often underutilised) both allow a better understanding of climate, glacier fluctuations and human migration (Biagi and Cremaschi, 1988; Zhang and Li, 2002; Brantingham et al., 2003; Meyer et al., 2009; Nussbaumer and Zumbühl, 2012; Dixon et al., 2014). For example, Meyer et al. (2009) used geomorphologic, palaeoenvironmental and archaeobotanical data to reveal the earliest evidence of human activities in the High Himalaya, and made associated links between climatic change, glacier fluctuations and human migration patterns. Zhang and Li (2002) used the handprints and footprints of Homo sapiens on hot spring travertine and the remnants of a fireplace, to suggest that the Tibetan plateau was not occupied by an ice cap during the Last Glacial Maximum (LGM).

In brief, existing glacio-archaeological remains along with historical maps and achieves provide a direct indication of past climate, glacier fluctuations and human migration. This is particularly true within the Himalaya, where occupation can only occur on glacier-free sectors of the landscape, which also provide access to water, materials for fuel, and productive soils (Meyer et al., 2009).

Ruins within the Tharang glacier end moraine complex, in the Miyar basin, Lahaul Himalaya, represents a valuable glacio-archaeological record. The particular significance of the Tharang glacier ruins results from their proximity to the Tharang glacier, and the availability of historic maps that mark the positions of contemporary glaciers and archaeological remains. In this study, we present glacio-archaeological, geomorphological and historical evidence of former settlement within the Tharang glacier end moraine complex, and discuss our

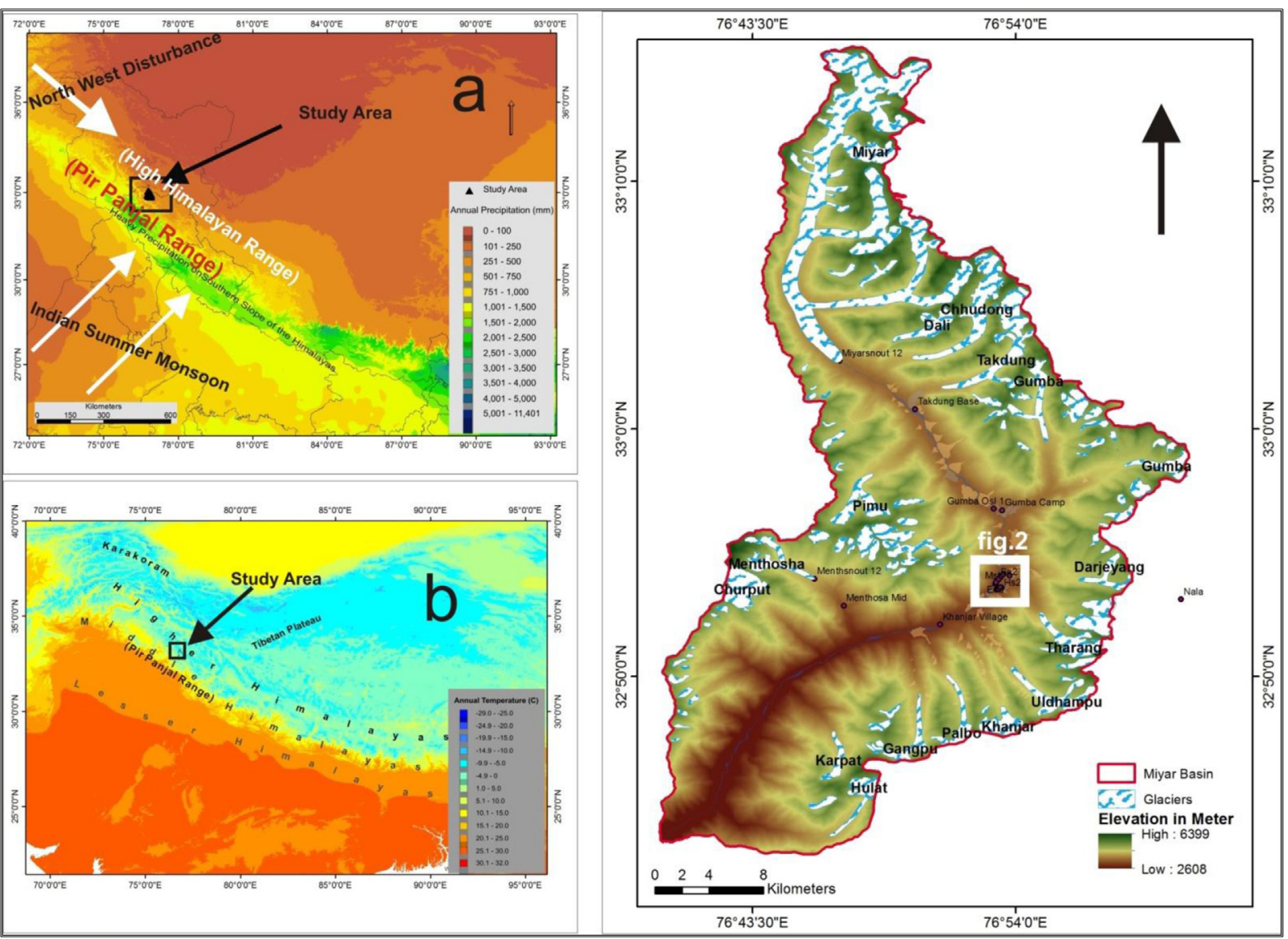

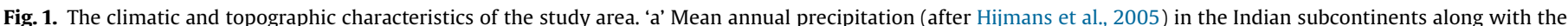

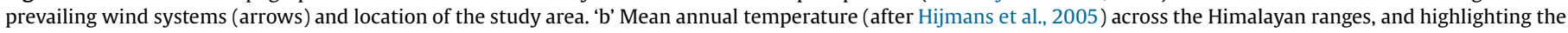
location of the study area. 'c' Digital Elevation Model (SRTM, $30 \mathrm{~m}$ ) of the study area (Miyar basin) along with major glaciers (as in year 2016). 
findings in the context of existing glacial and other palaeo-climatic proxies from the North West Himalaya. In so doing, this study provides a framework for understanding the history of glaciation and human occupation in the Lahaul Himalaya during the last 1000 years.

\section{Materials and methods}

\subsection{Study area}

The study area is located in the Miyar basin, a major sub-basin of the Chandrabhaga river (Chenab) of the Lahaul and Spiti district of Himachal Pradesh, India (Fig. 1). The basin extends from $32^{\circ} 42^{\prime} 36^{\prime \prime} \mathrm{N}$ to $33^{\circ} 15^{\prime} 24^{\prime \prime} \mathrm{N}$ and $76^{\circ} 40^{\prime} 12^{\prime \prime} \mathrm{E}$ to $77^{\circ} 1^{\prime} 15^{\prime \prime} \mathrm{E}$, covering an area of $\sim 963.85 \mathrm{~km}^{2}$, of which $\sim 21.6 \%\left(208.2 \mathrm{~km}^{2}\right)$ is covered by the contemporary glaciers (as of 2016). The basin contains a cluster of 92 glaciers of varying dimensions and types, out of which Miyar glacier is the longest ( $27 \mathrm{~km}$ ) (Saini, 2012; Deswal et al., 2017). Topographically, the Miyar basin is sandwiched between the lofty Pir Panjal to the south and High Himalayan Range to the north. The Pir Panjal constitutes a barrier for the northward approaching Indian Summer Monsoon (ISM), resulting in a strong moisture gradient of increasing aridity towards the north (Owen et al., 1996; Bhutiyani et al., 2007). Observational records suggest that precipitation and temperature vary according to aspect, altitude, and prevailing wind directions (Saini, 2012). The basin is dominated by severe and long winters that last from September to May. During the winter months, temperatures fall to $-15^{\circ} \mathrm{C}$. However, during the summer months (May-September), daytime temperature rises to $35^{\circ} \mathrm{C}$ but can fall as low as $-2^{\circ} \mathrm{C}$ during the night time or on any cloudy day of the Summer (Saini, 2012). Annual precipitation is dominated by snowfall, controlled by the Mid Westerlies (Benn and Owen, 1998). The contemporary Equilibrium Line Altitude (ELA) lies between 4900 and $5200 \mathrm{~m}$ a.s.l (Saini, 2012; Deswal et al., 2017).

In 2018, the highest sedentary village in the Miyar basin is Khanjar, situated at $3500 \mathrm{~m}$ a.s.l. (Fig. 1) However, during June and August, the alpine pastures (area above $3500 \mathrm{~m}$ a.s.l.) are used for seasonal grazing. The main valley above $3200 \mathrm{~m}$ a.s.l. has an open ' $U$ ' shaped cross profile, and is broadest ( $\sim 2 \mathrm{~km}$ ) at Gumba ( $3800 \mathrm{~m}$ a.s. 1.), with a valley floor filled with Quaternary and Holocene glacial sediments (Deswal et al., 2017), providing abundant space for transhumance. The Holocene moraine complex between Khanjar and Gumba encompasses several sites of ruins, the most prominent of which are Tharang, Phundang and Patam, located upon the Tharang glacier forefield, between 3700 and $3800 \mathrm{~m}$ a.s.l. Tharang glacier is one of the major glaciers of the Miyar basin. During the early Holocene advance (Khanjar stage), the glacier descended to $\sim 3595 \mathrm{~m}$ a.s.l. in comparison to its present terminus position at $\sim 4471 \mathrm{~m}$ a.s.l. Thus, the glacier terminated $\sim 880 \mathrm{~m}$ below and $\sim 4.96 \mathrm{~km}$ beyond its current position (Deswal et al., 2017). The ruins of Tharang are confined within the lateral moraine of this advance, and are particularly important because of their proximity to the glacier, and due to their presence on historical maps and documents.

\subsection{Mapping}

Mapping of the geo-archaeological and geomorphological features was conducted over the course of five field expeditions during 2008-2016. The archaeological features such as relict house structures, agriculture fields and irrigation channels were mapped at a scale of 1:5000. The geomorphological features such as glacier margins, ponds, moraines, and hummocks were mapped at a scale of $1: 10,000$. High resolution satellite images provided by Google Earth Pro engine were used to validate and upgrade the field maps. Google earth 3D visualization of terrain between the scales of $0.1-3$ vertical exaggeration was used for mapping features such as moraines, hummocks, ablation valleys and the settlements, agriculture fields, water-harvesting ponds and irrigation channels (locally called "Kuhls").

The extent and shape of the glaciers on the historical maps (Great Trigonometric Map 1874 and Harcourt's Map 1871) has been used as a reference for the historical positions of the glaciers. The position and extent of glacier expansion marked on the historical maps have been verified through field expeditions carried out between 2006 and 2016 for selected glaciers (Miyar, Pimu, Menthosa, Tharang, Karpat and Uldhampu). The Survey of India topographical sheets (No 52-C-12, 52-C-16, 52-D-09, 52-D-10, 52-D-13, 52-H-1), surveyed during 1962-1966, were used to derive information about feature and settlement names within the study area. In order to constrain the chronology of the settlements, organic rich samples were extracted from the dilapidated remains of the Tharang end moraine settlements for Radiocarbon $\left({ }^{14} \mathrm{C}\right)$ dating. The glacial chronology of the moraines is based on the Optically-Stimulated Luminescence (OSL) dates of Deswal et al., 2017.

\subsection{Radiocarbon sampling}

Fourteen radiocarbon samples, including charcoal (2), wood (7), horn (1), bone (2) and soil (2) were obtained from the ruins to establish the chronology of settlement (Tables 1 and 2. Of these fourteen samples, ten were collected from the Tharang ruins, three from the Patam ruins, and one from the Phundang ruins (Table 1). The UBA-30065 sample (bone) was extracted from a hearth

Table 1

Characteristics of radiocarbon $\left({ }^{14} \mathrm{C}\right)$ samples.

\begin{tabular}{|c|c|c|c|c|c|c|}
\hline Sl No. & Lab Code & material type & latitude & longitude & altitude (m) & site location \\
\hline 1 & UBA-30075 & Wood/charcoal (Hearth) & $32^{\circ} 53.750^{\prime} \mathrm{N}$ & $76^{\circ} 53.201^{\prime} \mathrm{E}$ & 3739 & Tharang \\
\hline 2 & UBA-30064 & Charcoal (Hearth) & $32^{\circ} 53.342^{\prime} \mathrm{N}$ & $76^{\circ} 52.969^{\prime} \mathrm{E}$ & 3681 & Patam \\
\hline 3 & UBA-30076 & Soil (Hearth) & $32^{\circ} 53.753^{\prime} \mathrm{N}$ & $76^{\circ} 53.196^{\prime} \mathrm{E}$ & 3731 & Tharang \\
\hline 4 & UBA-30077 & Soil (Cattle shed) & $32^{\circ} 53.760^{\prime} \mathrm{N}$ & $76^{\circ} 53.195^{\prime} \mathrm{E}$ & 3734 & Tharang \\
\hline 5 & UBA-30074 & Wood (hearth) & $32^{\circ} 53.756^{\prime} \mathrm{N}$ & $76^{\circ} 53.197^{\prime} \mathrm{E}$ & 3730 & Tharang \\
\hline 6 & UBA-30078 & Horn & $32^{\circ} 53.849^{\prime} \mathrm{N}$ & $76^{\circ} 53.210^{\prime} \mathrm{E}$ & 3739 & Tharang \\
\hline 7 & UBA-30069 & Wood (hearth) & $32^{\circ} 53.792^{\prime} \mathrm{N}$ & $76^{\circ} 53.197^{\prime} \mathrm{E}$ & 3729 & Tharang \\
\hline 8 & UBA-30072 & Bone (Hearth) & $32^{\circ} 53.735^{\prime} \mathrm{N}$ & $76^{\circ} 53.189^{\prime} \mathrm{E}$ & 3735 & Tharang \\
\hline 9 & UBA-30065 & Bone (Hearth) & $32^{\circ} 53.499^{\prime} \mathrm{N}$ & $76^{\circ} 53.208^{\prime} \mathrm{E}$ & 3699 & Phundang \\
\hline 10 & THMCSO2 & Pine Wood & $32^{\circ} 53.342^{\prime} \mathrm{N}$ & $76^{\circ} 52.970^{\prime} \mathrm{E}$ & 3681 & Patam \\
\hline 11 & THMCS03 & Pine Wood & $32^{\circ} 53.342^{\prime} \mathrm{N}$ & $76^{\circ} 52.975^{\prime} \mathrm{E}$ & 3681 & Patam \\
\hline 12 & THMCS04 & Pine Wood & $32^{\circ} 53.845^{\prime} \mathrm{N}$ & $76^{\circ} 53.210^{\prime} \mathrm{E}$ & 3738 & Tharang \\
\hline 13 & THMCS05 & Pine Wood & $32^{\circ} 53.848^{\prime} \mathrm{N}$ & $76^{\circ} 53.210^{\prime} \mathrm{E}$ & 3737 & Tharang \\
\hline 14 & THMCS06 & Pine Wood & $32^{\circ} 53.850^{\prime} \mathrm{N}$ & $76^{\circ} 53.210^{\prime} \mathrm{E}$ & 3738 & Tharang \\
\hline
\end{tabular}

Note: Samples were superficially covered with shattered stone, and have been dug out. However, the horn sample was openly exposed on an animal sacrifice point. The UBA samples were processed at 14CHRONO Centre of Queen's University Belfast, Northern Ireland, United Kingdom, whereas the THMCS were processed at Inter-University Accelerator Centre (IUAC), New Delhi. 
Table 2

Calibrated radiocarbon dates arranged in chronological order.

\begin{tabular}{|c|c|c|c|c|c|}
\hline Sl. No. & Lab Code & ${ }^{14} \mathrm{C}$ age & lower cal range $\mathrm{AD}$ & upper cal range $A D$ & $\begin{array}{l}\text { median age } \\
\text { AD }\end{array}$ \\
\hline 1 & THMCS06 & $1058 \pm 44$ & 885 & 1040 & 980 \\
\hline 2 & THMCS04 & $892 \pm 42$ & 1032 & 1221 & 1133 \\
\hline 3 & THMCSO3 & $860 \pm 42$ & 1044 & 1101 & 1179 \\
\hline 4 & UBA-30075 & $838 \pm 28$ & 1159 & 1260 & 1206 \\
\hline 5 & THMCS05 & $826 \pm 42$ & 1052 & 1080 & 1212 \\
\hline 6 & UBA-30064 & $654 \pm 21$ & 1283 & 1317 & 1358 \\
\hline 7 & UBA-30076 & $489 \pm 22$ & 1412 & 1444 & 1429 \\
\hline 8 & UBA-30077 & $378 \pm 27$ & 1446 & 1524 & 1501 \\
\hline 9 & THMCSO2 & $393 \pm 41$ & 1462 & 1642 & 1556 \\
\hline 10 & UBA-30074 & $327 \pm 21$ & 1488 & 1603 & 1565 \\
\hline 11 & UBA-30078 & $212 \pm 34$ & 1641 & 1690 & 1768 \\
\hline 12 & UBA-30069 & $123 \pm 22$ & 1681 & 1739 & 1836 \\
\hline 13 & UBA-30072 & $108 \pm 32$ & 1693 & 1727 & 1836 \\
\hline 14 & UBA-30065 & $101 \pm 27$ & 1684 & 1734 & 1840 \\
\hline
\end{tabular}
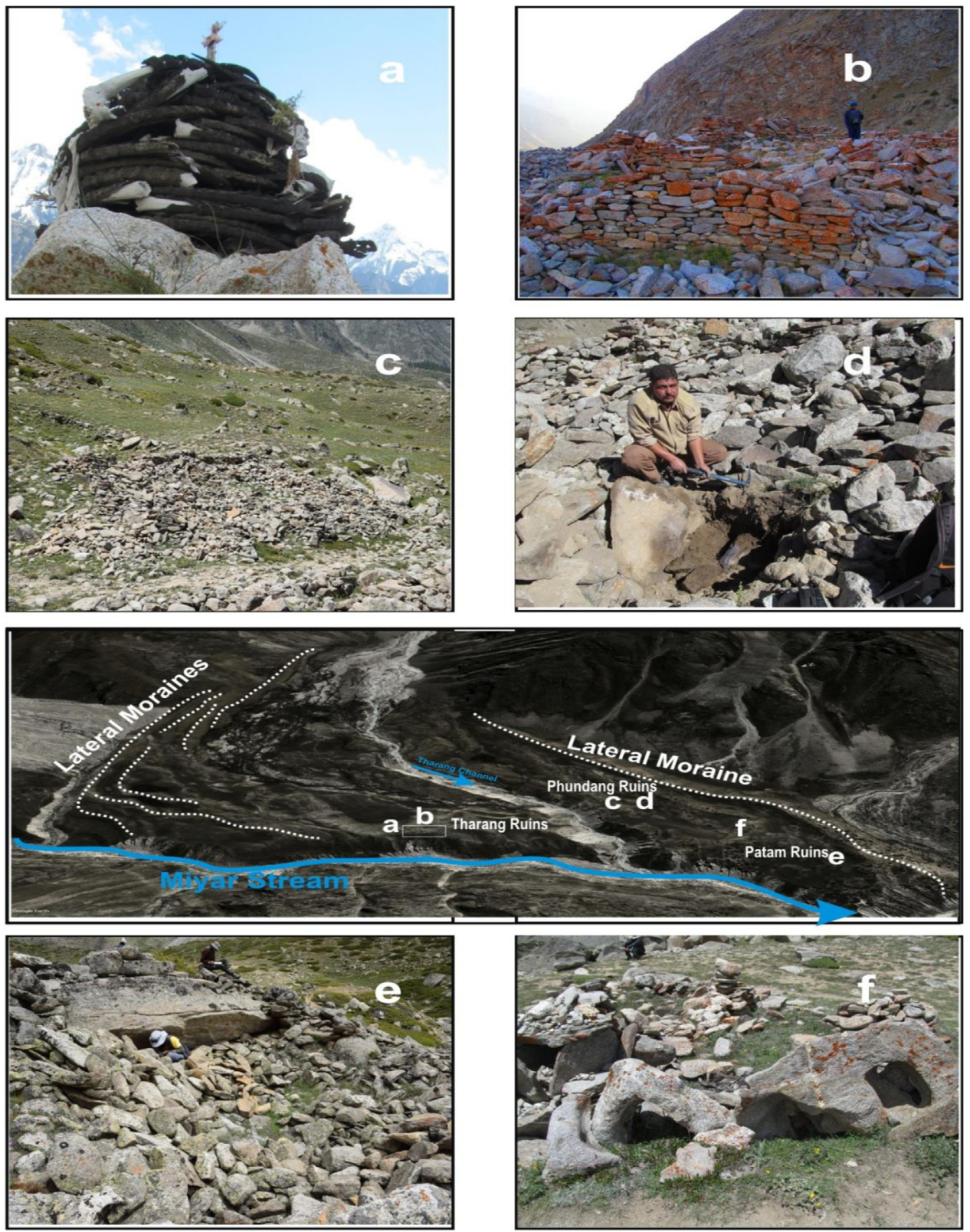

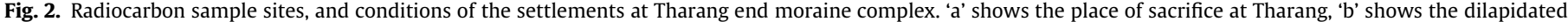

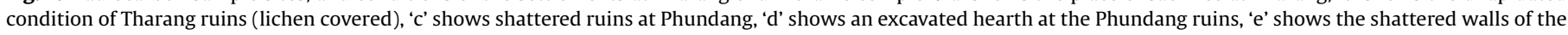
Patam ruins and a hearth covered with a big boulder, ' $\mathrm{f}$ ' shows the place of worship between Phundang and Patam ruins. 


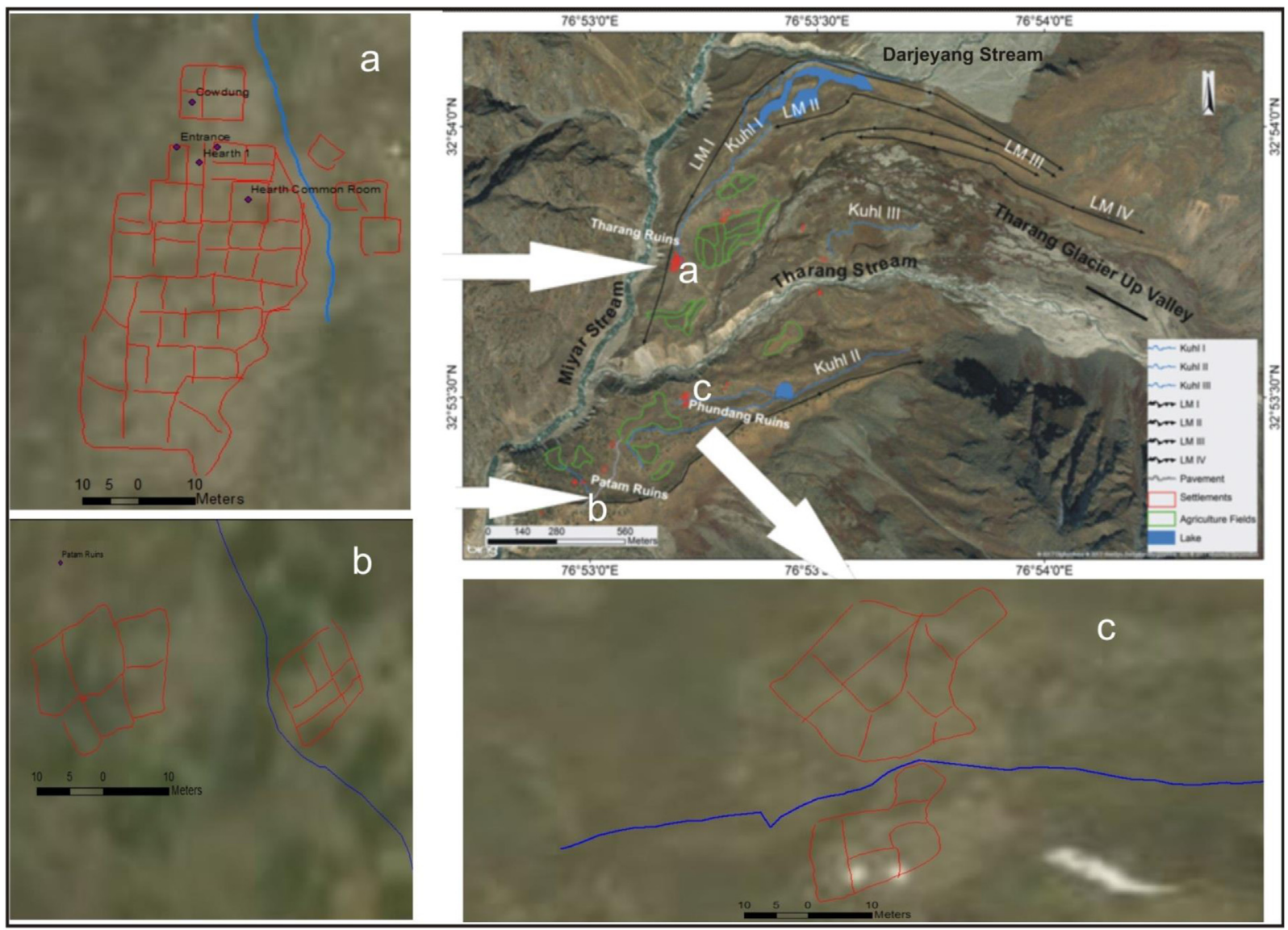

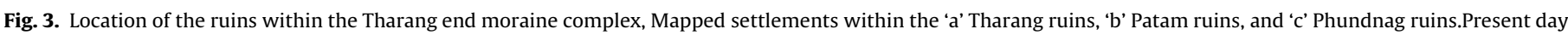

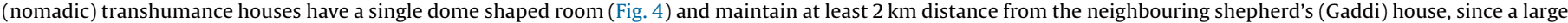
area is required for the grazing of the sheep-goat flocks (on an average 300 sheep and goats each).

underneath a stone pile at Phundang ruins (Fig. 2), and likely represents the earliest record of permanent human settlement in the area. Another bone sample (UBA-30072) was extracted from the Tharang complex in a similar setting to UBA-30065 (mentioned above) (Fig. 2).

The wood sample (UBA-30069) was found in a hearth covered by stone, within the Tharang complex. The Ibex (Capra sibirica hemalayanus) horn sample (UBA-30078) was from a place of worship within the Tharang complex (Fig. 2). This sample holds much significance in interpreting the history, as there is a practice, within the valley, of placing animal heads/trophies on the walls/tops of temples. Each village has a separate deity and place of worship, generally on a prominent landform. A wood sample (UBA-30074) was extracted from a hearth within the Tharang ruins, after removing piles of stones. The wood was an integral part of the hearth structure and found along with small pieces of charcoal. The sample of wood may be the remnants of fuel wood once stored for use within the fire.

The conditions of the hearths, within each house, were similar. One soil sample (UBA-30077) was dug-out from the cattleshed (a separate structure of four rooms) at Tharang. The four room structure of $20^{\prime} \times 20^{\prime}$ is full of organically rich soil, absent in other rooms. The second soil sample (UBA-30076) was picked up from a buried hearth in a house. This was burnt (dark) and had carbon layered on the hearth stone. One charcoal sample (UBA-30064) was picked from a buried hearth at Patam (Fig. 2). The second wood/charcoal sample (UBA-30075) is from a living room (the biggest room) at Tharang (Fig. 3). It was recovered from a hearth, located in the center of the room, and partially covered by stone and soil, along with charcoal and small pieces of un-burnt wood. In addition to the hearth material, five samples of pine wood (THMCS02, THMCS03, THMCS04, THMCS05, and THMCS06) were obtained from these ruins, excavated from the piles of stones (Table 1). The first two juniper pine samples belong to Patam and the other three to Tharang.

\subsection{Radiocarbon dating}

The fourteen Radiocarbon samples were processed following Reimer et al. (2015). As per the lab protocol, the samples were processed at three stages; namely pre-treatment, combustion and graphitization, and finally age determination, using Accelerator Mass Spectrometry (AMS). At pre-treatment stage, the samples containing charcoal, wood and sediment (UBA-30064, 30069, 30074, 30075, UBA 30076, 30077, THMCS02, 03, 04, 05, 06) were placed in a clean $100 \mathrm{ml}$ beaker and immersed in $\mathrm{HCL}(4 \%, 30-50 \mathrm{l})$. The samples were heated on a hotplate $\left(80^{\circ} \mathrm{C}\right.$ for $\left.2-3 \mathrm{~h}\right)$, and were

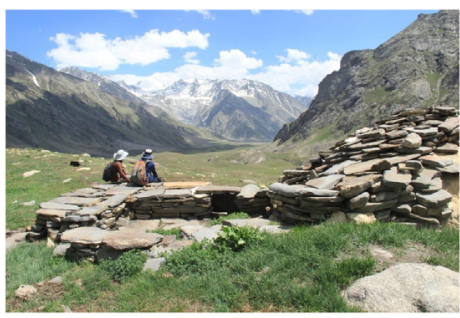

Fig. 4. Contemporary nomad (Gaddi) settlement (single dome) at Gumba 

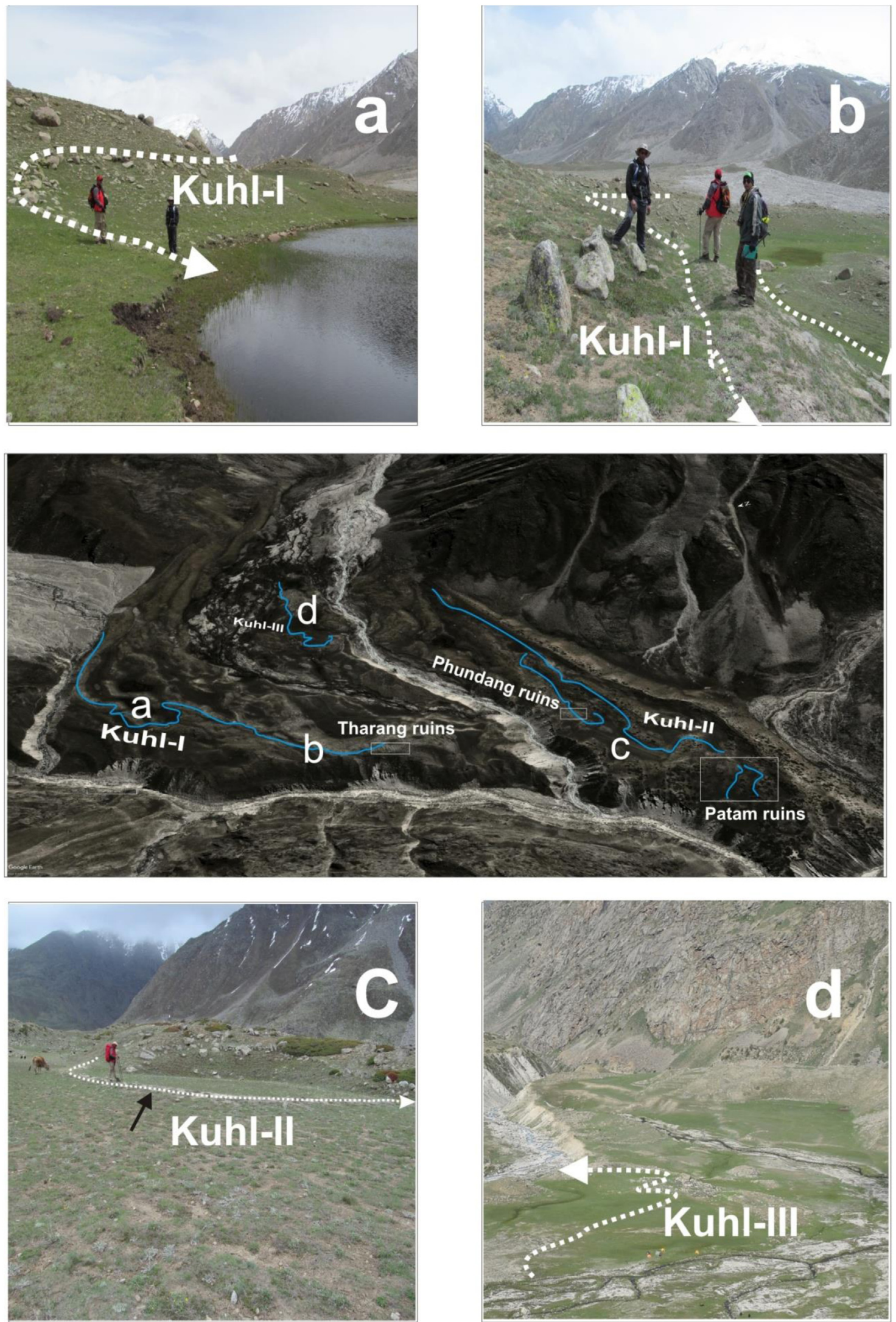

Fig. 5. Irrigation channels (Kuhls) marked within the Tharang end moraine complex. 'a' A branch of Kuhl-I, pouring into a lake for storage, 'b' The branch of Kuhl-I just before the Tharang ruins, 'c' The well bounded Kuhl-II in the fields of the Phundang ruins. 'd' Kuhl-III along the Tharng channel. 


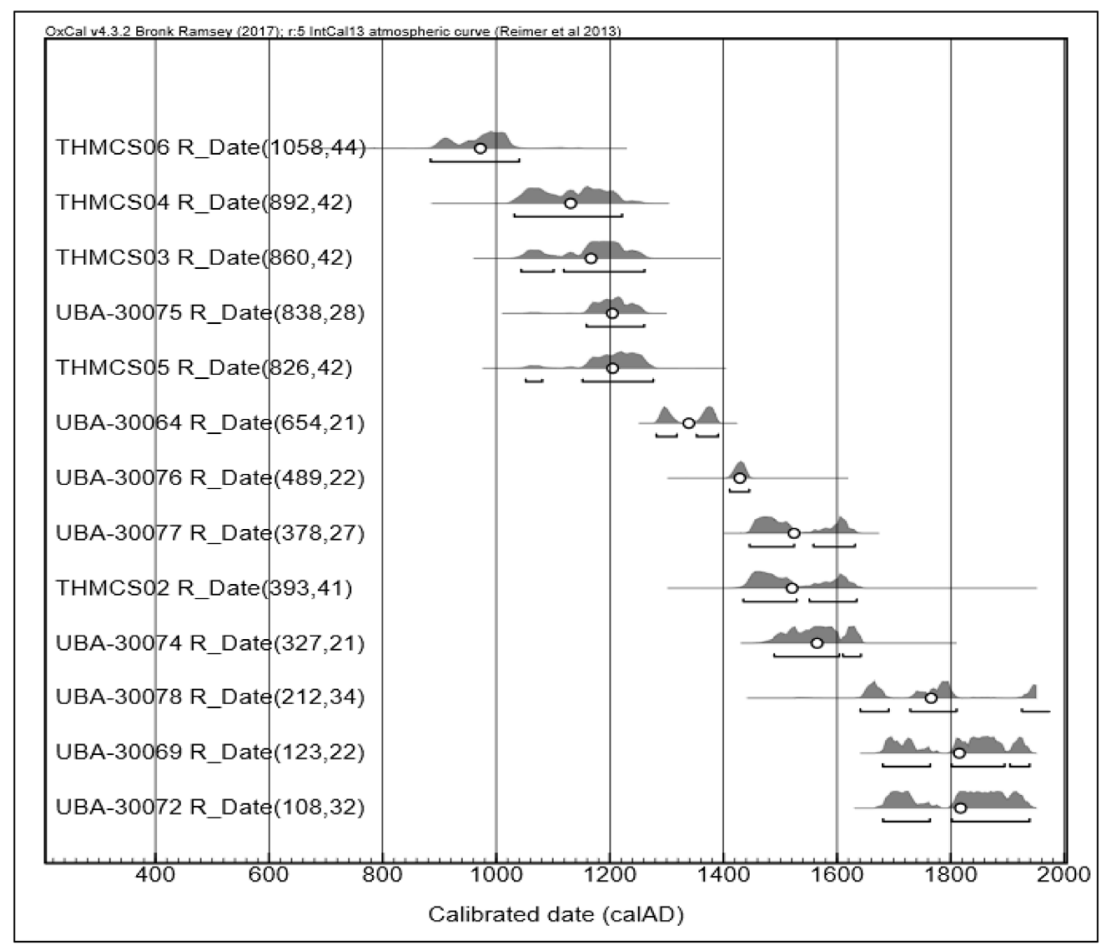

Fig. 6. Calibrated radiocarbon dates of samples extracted from ruins within the Tharang end moraine complex.

subsequently washed with deionised water until neutral. The bone samples (UBA-30065,30072, 30078) were prepared following ABA treatment, gelatinization (Longin, 1971) and ultrafiltration (Brown et al., 1988) using the Vivaspin $®$ filter cleaning method (Bronk Ramsey et al., 2004). Subsequently, the dried samples were combusted to carbon dioxide at $850^{\circ} \mathrm{C}$ for $8 \mathrm{~h}$ into quartz tubes with an excess of copper oxide and silver foil, sealed under a vacuum. At graphitisation stage, zinc with an iron catalyst was used to remove the oxygen from the carbon dioxide. The ${ }^{14} \mathrm{C} /{ }^{12} \mathrm{C}$ and ${ }^{13} \mathrm{C} /{ }^{12} \mathrm{C}$ ratios were measured by AMS on an NEC $0.5 \mathrm{MV}$ compact accelerator. Sample ${ }^{14} \mathrm{C} /{ }^{12} \mathrm{C}$ ratios were background corrected and normalised to the HOXII standard (SRM 4990C; National Institute of Standards and Technology). The radiocarbon ages were corrected for isotope fractionation using the AMS measured $\delta 13 \mathrm{C}$ which accounts for both natural and machine fractionation. The fractionation and background corrected quantity of fractionation ${ }^{14} \mathrm{C}$ were calculated following Reimer et al. (2004). The value of fractionation ${ }^{14} \mathrm{C}$ is for two minute exposure of caesium on the sample. The Conventional Radiocarbon Ages (CRA) were determined using the Libby half-life of 5568 years, following the methods of Stuiver and Polach (1977).The CRAs were calibrated in the OxCal v4.3.2 (online) radiocarbon calibration program 19862016, using the IntCal13 northern hemisphere calibration curves (Reimer, 2013). The uncertainties for the calibrated ages are given up to $2 \sigma$ (Table 2 ).

\section{Results}

\subsection{Settlements and irrigation system at Tharang end moraine complex}

A number of abandoned settlements (in ruins) are located between Khanjar and Gumba. Most are concentrated within the Tharang glacier end moraine complex area (Fig. 3), where three abandoned village sites (Tharang, Phundang and Patam) were identified and dated. Based on mapping, it is apparent that Tharang was the largest village (with a group of $\sim 50$ rooms spread over $\sim 1700 \mathrm{~m}^{2}$ ) (Fig. 3), followed by Patam (5 separate groups of settlements having 6 rooms on an average) and Phundang (3 separate settlements having 7 rooms on an average) (Fig. 3). In terms of size, number and proximity, these settlements differ from nomadic type structures.

Based on field mapping, the study identified three Kuhls (irrigation channels marked as Kuhl-I, II, III), draining into the villages and fields (Figs. 3 and 5). Kuhls were constructed to divert water from the streams for domestic and irrigation needs. Kuhl-I, originates at the Darjeyang stream, runs along the crest of the highest lateral moraine (LM-I) in the north, and extends up to the open yard of the Tharang ruins (Figs. 3 and 5). The Kuhls are well bounded by two-sided stone bunding (Fig. 5). Before reaching the settlement, Kuhl-I debouched into two sequential lakes (upper and lower lakes), within the recessional end moraine complex (Figs. 3 and 5).

We presume that when the upper lake reached its threshold, water overflowed to the lower lake and thus sufficient water storage and secure supply was ensued for both domestic and irrigation purposes. A distributory channel was constructed from the lower lake to feed the irrigation needs of the field further down the ridge.

Kuhl-II is located on the left flank of the Tharang channel (Figs. 3 and 5). It originates from the eastern edge of $L M-I$, marked on the left flank of the Tharang channel. This Kuhl flows through the ablation valley between $L M-I$ and $L M-I I$, feeding Phundang ruins and associated fields. Kuhl-III is located in the center of the outwash plain, and anabranches water from Tharang stream, and feeds a few settlements along the hummocks (Figs. 3 and 5). Two sites for performing religious rituals, one at Tharang and another between Phundang and Patam, are still present, indicating religious and cultural practices (Fig. 2).

\subsection{Chronology}

The Radiocarbon ${ }^{14} \mathrm{C}$ chronology suggests that the ruins of the Tharang end moraine complex were occupied between 980 and 

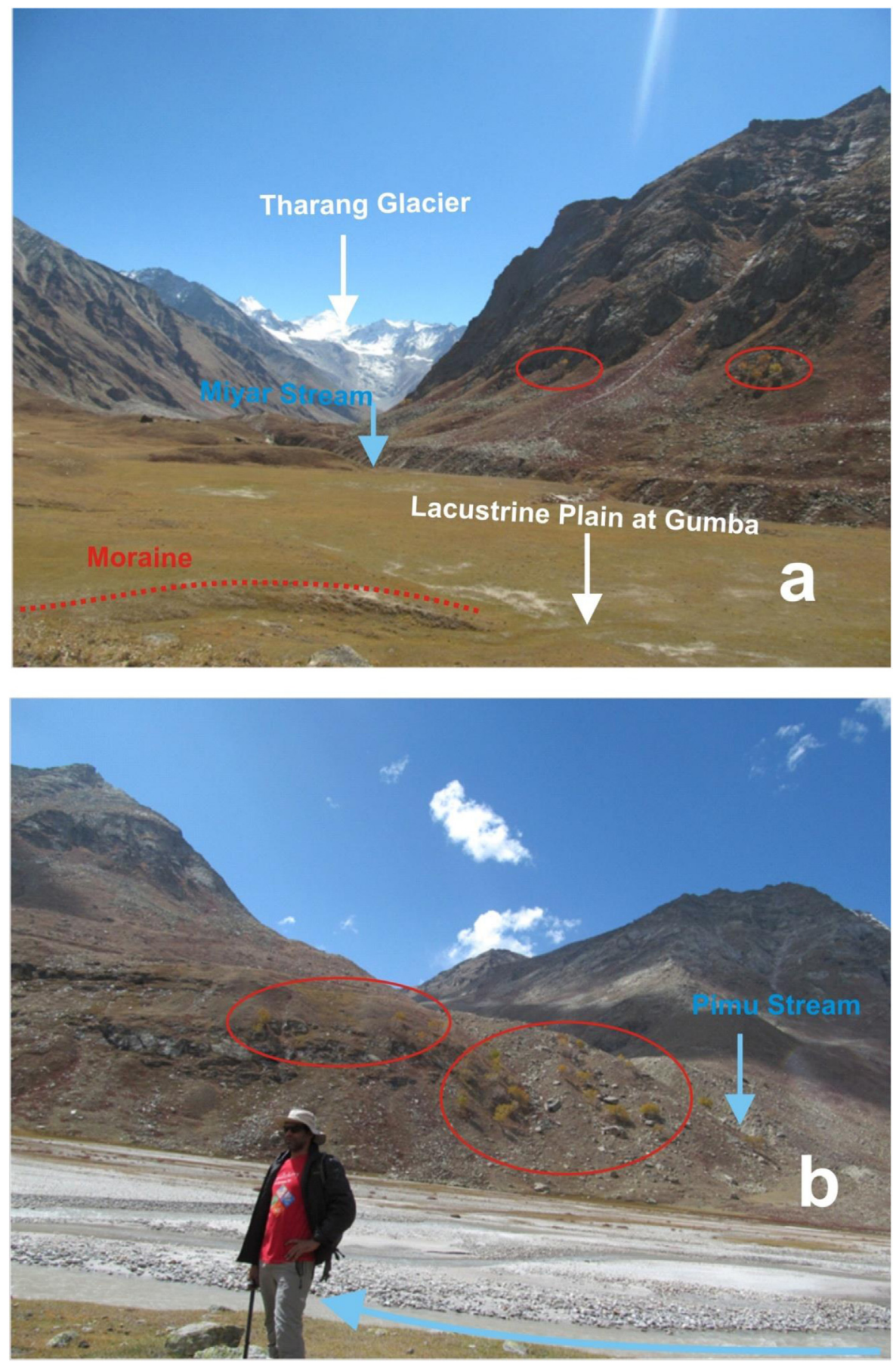

Fig. 7. Patches of trees at Gumba (a) and Pimu base (b).

1840 CE (Table 2, Fig. 6). The calibration of the first six dates indicates lower ages of 885, 1032, 1044, 1075, and $1052 \mathrm{CE}$, and upper ages of 1040,1212, 1101, 1260, and 1080 CE (Table 2). The median age of these samples varies from $980 \mathrm{CE}$ to $1358 \mathrm{CE}$ (Table 2 and Fig. 6), encompassing the majority of the Medieval Warm Period (i.e., 800-1300 CE; Mann, 2002). These calibrated dates are based on the charcoal (firewood in hearth) and excavated pine wood samples. The soil samples (UBA 30076 and 30077), extracted from the cattle-shed and hearth (Table 1) are important as they indicate settled human activity at these sites. At 95\% confidence level, the sample UBA-30076 suggests a median date of $1429 \mathrm{CE}$, with a time span lasting between 1412 and 1444 CE (Table 2).
Sample UBA-30077 suggests a life span ranging between 1446 and $1631 \mathrm{CE}$, with a median date of $1501 \mathrm{CE}$ (Table 2 and Fig.6). Samples THMCS02 and UBA-30074 indicate a time span of 14621642 and 1488-1641 CE, respectively, with median dates of 1556 and 1565 CE. The Ibex horn (UBA-30078) yielded a time span of 1641-1949 CE, with a median calendar age of $1768 \mathrm{CE}$, at a $95 \%$ confidence level (Table 2). Samples UBA-30069, 30072 and 30065 yielded the most recent dates i.e. 1836, 1836 and 1840 CE (median age), respectively. These samples contained wood and bone materials extracted from the hearths in Tharang and Phundang, and suggest the time period when the inhabitants probably abandoned these villages. Since the dates suddenly end at 1836, 


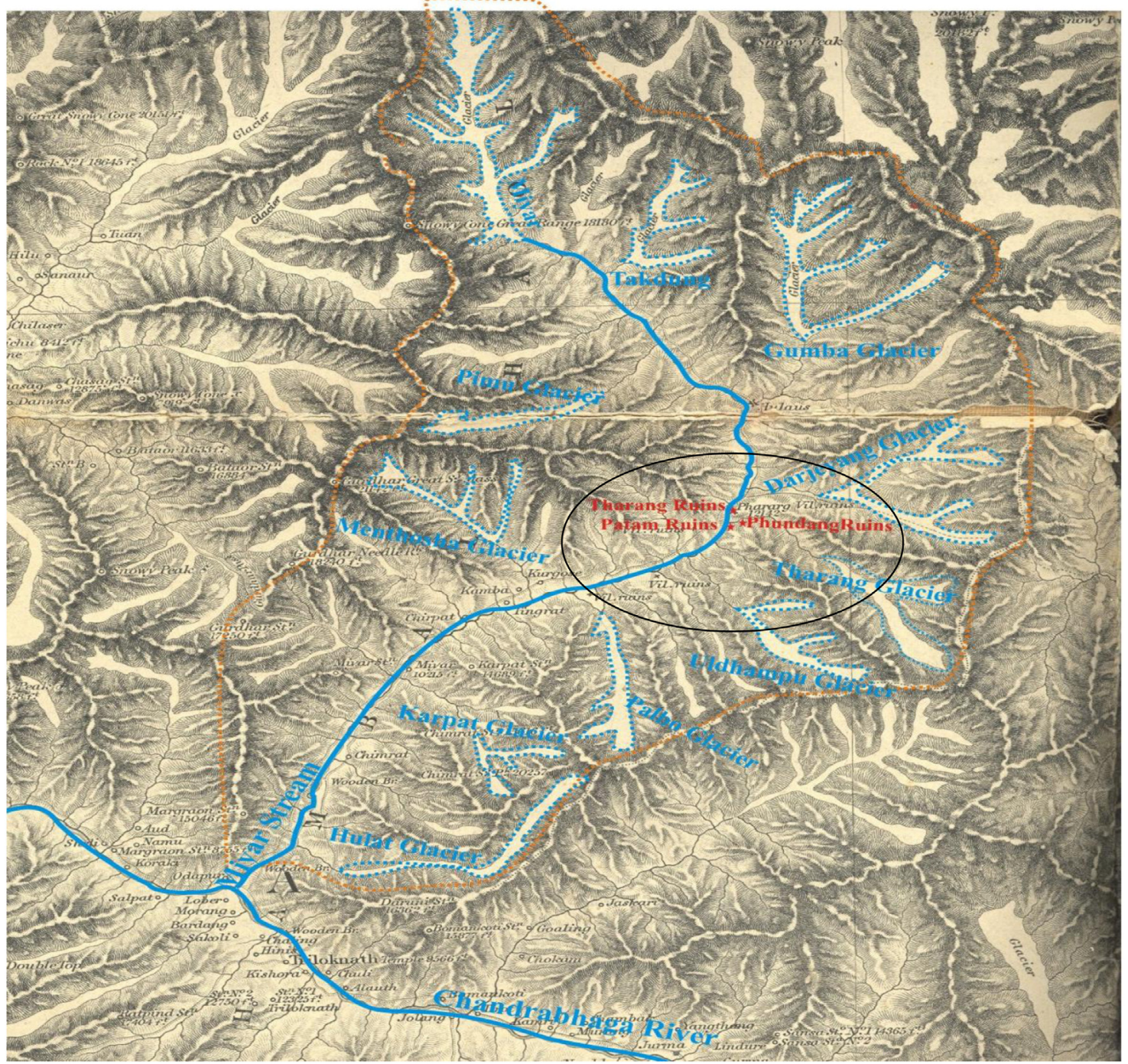

Fig. 8. The Great Trigonometric Survey (GTS) Map (1874) of the Miyar basin and surrounding regions. Modern glaciers and the study site of the Tharang glacier end moraine complex are also shown.

1836, and 1840, this suggests that the people of these villages left together, and likely for the same reason.

\section{Discussion}

\subsection{Implications of charcoal and irrigation networks}

This study reports nine samples of charcoal and wood from hearths, that suggest the settlements used firewood for the purpose of cooking. At present, the tree line of pine is located at $3650 \mathrm{~m}$ a.s.l., almost $5 \mathrm{~km}$ down-valley from the ruins (Fig. 1). In these high altitude regions, firewood is a daily use item, required for cooking and heating throughout the year. Given this daily requirement, it is probable that wood was obtained locally (rather than from $5 \mathrm{~km}$ away), and that the area proximal to the Tharang end moraine complex had vegetation cover that differed from the present day. In the modern landscape, Juniper and Birch trees are found, but only in small patches at Tharang $\left(32^{\circ} 53^{\prime} 25.38^{\prime \prime} \mathrm{N} \&\right.$ $\left.76^{\circ} 54^{\prime} 18.26^{\prime \prime} \mathrm{E}\right)$, Gumba (32 $\left.56^{\prime} 35.45^{\prime \prime} \mathrm{N} \& 76^{\circ} 52^{\prime} 56.17^{\prime \prime} \mathrm{E}\right)$ and Pimu base $\left(32^{\circ} 59^{\prime} 32.11^{\prime \prime} \mathrm{N} \& 76^{\circ} 50^{\prime} 24.79^{\prime \prime} \mathrm{E}\right)$ (Fig. 7). The inference that vegetation in this region differed significantly in the recent past, is generally supported by temperature and precipitation data for the Western Himalaya over the past millennium (Yadav, 2011a, 2011b;
Yadav et al., 2011; Yadav and Bhutiyani, 2013). For example, Yadav et al. (2011) report periods of protracted warmth from the $11^{\text {th }}$ to $15^{\text {th }}$ centuries, and a decrease in mean summer temperatures since the $15^{\text {th }}$ century; with the $18^{\text {th }}$ and $19^{\text {th }}$ centuries being the coldest interval of the last millennium. It is quite possible that during these warm periods, the Miyar basin (even at the altitude of the Tharang moraine complex) contained extensive vegetation cover, which included trees and shrubs.

It is also possible that the treeline in the area has changed due to non-climatic factors (Holtmeier and Broll, 2005). For example, the agricultural and domestic use of wood may have led to scarcity, and a decline of forest cover, as has been reported in other parts of the world (Etter and Villa, 2000; Caldararo, 2002; Ringrose et al., 2002; Miehe et al., 2009). However, Borgaonkar et al. (2011) have suggested that the tree growth in parts of Himalaya has strong control of temperature than precipitation.

The present study indicates that within settlements of the Tharang end moraine complex, irrigation practices were common. For example, the settlements had at least three major irrigation channels (Kuhls) to serve domestic and agricultural needs. These channels likely indicate that people lived in moisture stressed conditions, similar to present day. The available tree-ring precipitation records for the north west Himalaya support our 
findings, and suggest that the 1300-1600 CE period was drier than present in parts of the adjacent regions of the study area (Singh and Yadav, 2005; Yadav, 2011a, 2011b; Yadava et al., 2016).

\subsection{Analysis of settlement chronology}

The consistent and overlapping ages (Fig.6) of the ruins suggest that the settlements thrived during 980-1840 CE (Table 2), a part of the Medieval Warm Period (800-1300 CE) and peak of the Little Ice Age period (1300-1600 CE) in the other parts of the world (Mann, 2002; Xu and Yi, 2014; Rowan, 2016). In the Miyar basin, present day conditions only allow permanent settlement at lower altitude sites, suggesting that climatic conditions were warmer during periods of settlement within the end moraine complex. These findings are consistent with palaeo-temperature (Yadav et al., 2011 ) and snowfall (Yadav and Bhutiyani, 2013) proxies, which suggest that the 1300-1600 CE period was generally warmer than the present day. By contrast, the period between the $18^{\text {th }}$ and $19^{\text {th }}$ centuries was the coldest interval of the last millennium, and coincided with increased snowfall. The snowfall proxy (Yadav and Bhutiyani, 2013) is based on the tree ring studies from the lower parts of the study area (Kukumseri, Udaipur, Madgram, Ratoli, Khursad and Tindi), but trends are considered characteristic of the wider study area.

The Great Trigonometric Survey (GTS) map (1874) of the basin (Fig. 8) further supports these results, as it marks the Tharang end moraine complex as ruins during the $1840 \mathrm{~s}-1860 \mathrm{~s}$ period. The GTS map along with map of Harcourt (1871) also shows Tharang glacier in an advanced position (relative to present) that appears to relate to the evidence of increased snowfall (Yadav and Bhutiyani, 2013) and other precipitation records from similar moisture stressed settings in north west Himalaya (Yadav, 2011a, 2011b; Yadava et al., 2016). These climate proxies, our radiocarbon chronology, and map records, show settlement abandonment occurred during a time of reduced temperature and increased snowfall, in the late 18 th and early $19^{\text {th }}$ centuries, when the basin also experienced a period of glacier advance. This glacier advance was likely driven by the increase in solid precipitation (Yadav and Bhutiyani, 2013) and reduction in temperature (Yadav et al., 2011). Glaciers from other parts of the Himalaya and Tibetan Plateau are also reported to have advanced during this period ( $\mathrm{Xu}$ and $\mathrm{Yi}$, 2014).

The GTS map suggests that, at the time of survey (i.e.,184050 ), the settlements were already abandoned. It is likely that the increased snowfall and decreasing temperature had an impact on crop production, given that barley and buck-wheat require comparatively stable temperatures and limited precipitation, and are the traditional crops still grown within the basin (though at lower altitudes than the ruins). Folk history in the contemporary villages of the Miyar valley also refers to the repeated failure of crops (cursed by the Flying Lama of Gumba) for years on an end, and mention of the last people surviving on boiled animal skin before finally migrating to lower areas within the Miyar basin. Two families with a lineage ( Phundang (Phun Phundang Pa) and Tharang (Chhe Chung Garad) continue to inhabit Tingret (3230 m a.s.l) and Urgos (3300 $\mathrm{m}$ a.s. 1.) villages.

\section{Conclusions}

Glacio-archaeological records from the Miyar basin indicate settled colonization within the Tharang glacier moraine complex $\left(>3500 \mathrm{~m}\right.$ asl) between the late 10 th and early $19^{\text {th }}$ centuries. Three, now abandoned, sites (Tharang, Phundang and Patam) suggest a prolonged period of settled agriculture that coincided with relatively warm temperatures and limited snowfall in the region. Although, the exact reason for abandonment of these sites is unknown, our study (supported by evidence from historical maps and published paleoclimate data) reveals a synchronicity between the timing of abandonment and a period of increased snowfall, reduced temperatures, and glacier expansion. Since this period, the settlements have remained uninhabited, despite an increase in the population and the expansion of market infrastructure for commercial crops in the basin. This likely indicates that the prevailing climate continues to restrict agricultural productivity in areas such as Tharang. We also suggest that there was almost no glacier expansion during the peak of the Little Ice Age (1300-1600 CE). However, further investigations are required, both in the basin and in the surrounding regions of the Himalaya, to better constrain the period of human colonization, and test the hypothesis of limited glacial expansion.

\section{Acknowledgements}

We acknowledge Space Application Centre (SAC/ISRO) and Department of Science \& Technology, Government of India for providing financial support to carry out this study. Critical comments of three anonymous reviewers helped us to improve the manuscript. We also acknowledge Jawaharlal Nehru University, New Delhi for providing necessary facilities during this research.

\section{References}

Bali, R., Khan, I., Sangode, S.J., Mishra, A.K., Ali, S.N., Singh, S.K., Tripathi, J.K., Singh, D. Sen, Srivastava, P., 2017. Mid- to late Holocene climate response from the Triloknath palaeolake, Lahaul Himalaya based on multiproxy data. Geomorphology 284, 206-219. doi:http://dx.doi.org/10.1016/j. geomorph.2016.10.028.

Barnard, P.L., Owen, L.A., Finkel, R.C., 2004a. Style and timing of glacial and paraglacial sedimentation in a monsoon-influenced high Himalayan environment, the upper Bhagirathi Valley, Garhwal Himalaya. Sediment. Geol. 165, 199-221. doi:http://dx.doi.org/10.1016/j.sedgeo.2003.11.009.

Barnard, P.L., Owen, L.A., Sharma, M.C., Finkel, R.C., 2004b. Late Quaternary (Holocene) landscape evolution of a monsoon-influenced high Himalayan valley, Gori Ganga, Nanda Devi, NE Garhwal. Geomorphology 61, 91-110. doi: http://dx.doi.org/10.1016/j.geomorph.2003.12.002.

Benn, D.I., Owen, La., 1998. The role of the Indian summer monsoon and the midlatitude westerlies in Himalayan glaciation: review and speculative discussion. J. Geol. Soc. London 155, 353-363. doi:http://dx.doi.org/10.1144/ gsjgs.155.2.0353.

Bhutiyani, M.R., Kale, V.S., Pawar, N.J., 2007. Long-term trends in maximum, minimum and mean annual air temperatures across the Northwestern Himalaya during the twentieth century. Clim. Change 85, 159-177. doi:http:// dx.doi.org/10.1007/s10584-006-9196-1.

Biagi, P., Cremaschi, M., 1988. The early Palaeolithic sites of the Rohri Hills (Sind, Pakistan) and their environmental significance). World Archaeol. 19, 422-433. doi:http://dx.doi.org/10.1080/00438243.1988.9980049.

Bolch, T., Kulkarni, a., Kaab, a., Huggel, C., Paul, F., Cogley, J.G., Frey, H., Kargel, J.S. Fujita, K., Scheel, M., Bajracharya, S., Stoffel, M., 2012. The state and fate of himalayan glaciers. Science 336 (80-), 310-314. doi:http://dx.doi.org/10.1126/ science. 1215828 .

Borgaonkar, H.P., Sikder, A.B., Ram, S., 2011. High altitude forest sensitivity to the recent warming: a tree-ring analysis of conifers from Western Himalaya, India. Quat. Int. doi:http://dx.doi.org/10.1016/j.quaint.2010.01.016.

Brantingham, P.J., Haizhou, M.A., Olsen, J.W., Gao, X., Madsen, D.B., Rhode, D.E., 2003. Speculation on the timing and nature of Late Pleistocene hunter-gatherer colonization of the Tibetan plateau. Chin. Sci. Bull. 48, 1510-1516. doi:http://dx. doi.org/10.1360/02wd0276.

Bronk Ramsey, C., Higham, T., Leach, P., 2004. Towards high-precision AMS: progress and limitations. Radiocarbon 46, 17-24. doi:http://dx.doi.org/10.1017/ S0033822200039308.

Brown, T.A., Nelson, D.E., Vogel, J.S., Southon, J.R., 1988. Improved collagen extraction by modified Longin method. Radiocarbon 30, 171-177. doi:http://dx. doi.org/10.2458/AZU_JS_RC.30.1096.

Caldararo, N., 2002. Human ecological intervention and the role of forest fires in human ecology. Sci. Total Environ. doi:http://dx.doi.org/10.1016/S0048-9697(01)01067-1.

Derbishyre and Owen, 1997. Quaternary glacial history of the Karakoram Mountains and Northwest Himalayas. A review. Quat. Int. 85-102.

Deswal, S., Sharma, M., Saini, R., Chand, P., Juyal, N., Singh, I., Srivastava, P., Ajai, Bahuguna, I.M., 2017. Late Holocene Glacier Dynamics in the Miyar Basin, Lahaul Himalaya, India. Geosciences 7, 64. doi:http://dx.doi.org/10.3390/geosciences7030064.

Dixon, E.J., Callanan, M.E., Hafner, A., Hare, P.G., 2014. The emergence of glacial archaeology. J. Glacial Archaeol. 1, 1-9. doi:http://dx.doi.org/10.1558/jga.v1i1.1. 
Etter, A., Villa, A., 2000. Andean forests and farming systems in part of the Eastern Cordillera (Colombia). Res. Dev. doi:http://dx.doi.org/10.1659/0276-4741(2000) 020[0236:AFAFSI]2.0.CO;2.

Fushimi, H., 1978. Glaciations in the Khumbu Himal (2). J. Jpn. Soc. Snow Ice 40, 71 77. doi:http://dx.doi.org/10.5331/seppyo.40.Special_71.

Gupta, A.A.K., Anderson, D.D.M., Overpeck, J.J.T., 2003. Abrupt changes in the Asian southwest monsoon during the Holocene and their links to the North Atlantic Ocean. Nature 421, 354-357. doi:http://dx.doi.org/10.1038/nature01340.

Harcourt, A.F.P.T., 1871. On the Himalayan Valleys : -Kooloo, Lahoul, and Spiti. J. R. Geogr. Soc. 41, 245-257.

Hijmans, R.J., Cameron, S.E., Parra, J.L., Jones, G., Jarvis, A., 2005. Very High Resolution Interpolated Climate Surfaces For Global Land Areas. Int. J. Climatol. 1978, 1965-1978. doi:http://dx.doi.org/10.1002/joc.1276.

Holtmeier, F.K., Broll, G., 2005. Sensitivity and response of northern hemisphere altitudinal and polar treelines to environmental change at landscape and local scales. Glob. Ecol. Biogeogr. doi:http://dx.doi.org/10.1111/j.1466822X.2005.00168.x.

Iwata, S., 1976. Late Pleistocene and Holocene Region, Moraines Khumbu in the Himal * Sagarmatha (Everest). Glaciol. Exped. to Nepal, Tokyo Metrop. Univ. doi: http://dx.doi.org/10.5331/seppyo.38.Special_109.

Juyal, N., Pant, R.K., Basavaiah, N., Bhushan, R., Jain, M., Saini, N.K., Yadava, M.G. Singhvi, A.K., 2009. Reconstruction of Last Glacial to early Holocene monsoon variability from relict lake sediments of the Higher Central Himalaya, Uttrakhand. India. J. Asian Earth Sci. 34, 437-449. doi:http://dx.doi.org/10.1016/ j.jseaes.2008.07.007.

Lehmkuhl, F., Owen, L.A., Derbyshire, E., 1998. Late Quaternary glacial history of northeast Tibet. J. Quat. Sci. 6, 121-142.

Liang, F., Brook, G.A., Kotlia, B.S., Railsback, L.B., Hardt, B., Cheng, H., Edwards, R.L, Kandasamy, S., 2015. Panigarh cave stalagmite evidence of climate change in the Indian Central Himalaya since AD 1256: Monsoon breaks and winter southern jet depressions. Quat. Sci. Rev. 124, 145-161. doi:http://dx.doi.org/10.1016/j. quascirev.2015.07.017.

Longin, R., 1971. New method of collagen extraction for Radiocarbon dating. Nature 230, 241-242. doi:http://dx.doi.org/10.1038/230241a0.

Mann, M.E., 2002. Little ice age. Encycl. Glob. Environ. Chang. 1, 504-509.

Mayewski, P.A., Jeschke, P.A., 1979. Himalayan and Trans-Himalayan Glacie Fluctuations Since AD 1812. Arct. Alp. Res. 11, 267-287.

Meyer, M.C., Hofmann, C.C., Gemmell, A.M.D., Haslinger, E., Häusler, H., Wangda, D. 2009. Holocene glacier fluctuations and migration of Neolithic yak pastoralists into the high valleys of northwest Bhutan. Quat. Sci. Rev. 28, 1217-1237. doi: http://dx.doi.org/10.1016/j.quascirev.2008.12.025.

Miehe, G., Miehe, S., Schlütz, F., 2009. Early human impact in the forest ecotone of southern High Asia (Hindu Kush, Himalaya). Quat. Res. 71, 255-265. doi:http:/ dx.doi.org/10.1016/j.yqres.2009.02.004.

Mishra, K.Parveen, Anoop, A., Schettler, G., Prasad, Sushma, Jehangir, A., Menzel, P. Naumann, Rudolf, Yousuf, Ar., Basavaiah, N., Deenadayalan, K., Wiesner, M.G., Gaye, B., 2014. Reconstructed late Quaternary hydrological changes from Lake Tso Moriri, NW Himalaya. Quat. Int. 371, 76-86. doi:http://dx.doi.org/10.1016/j. quaint.2014.11.040.

Murari, M.K., Owen, L.A., Dortch, J.M., Caffee, M.W., Dietsch, C., Fuchs, M., Haneberg, W.C., Sharma, M.C., Townsend-Small, A., 2014. Timing and climatic drivers for glaciation across monsoon-influenced regions of the Himalayan-Tibetan orogen. Quat. Sci. Rev. 88, 159-182. doi:http://dx.doi.org/10.1016/j. quascirev.2014.01.013.

Nesje, A., Dahl, S.O., 2003. The "Little Ice Age" - only temperature? Holocene 13,139145. doi:http://dx.doi.org/10.1191/0959683603hl603fa.

Nussbaumer, S.U., Zumbühl, H.J., 2012. The Little Ice Age history of the Glacier des Bossons (Mont Blanc massif, France): A new high-resolution glacier length curve based on historical documents. Clim. Change 111, 301-334. doi:http://dx. doi.org/10.1007/s10584-011-0130-9.

Orr, E.N., Owen, L.A., Murari, M.K., Saha, S., Caffee, M.W., 2017. The timing and extent of Quaternary glaciation of Stok, northern Zanskar Range, Transhimalaya, of northern India. Geomorphology 284, 142-155. doi:http://dx.doi.org/10.1016/j. geomorph.2016.05.031.

Orr, E.N., Owen, L.A., Saha, S., Caffee, M.W., Murari, M.K., 2018. Quaternary glaciation of the Lato Massif, Zanskar Range of the NW Himalaya. Quat. Sci. Rev. 183, 140156. doi:http://dx.doi.org/10.1016/j.quascirev.2018.01.005.

Owen, L.A., 2009. Latest pleistocene and holocene glacier fluctuations in the Himalaya and Tibet. Quat. Sci. Rev. 28, 2150-2164. doi:http://dx.doi.org/ 10.1016/j.quascirev.2008.10.020.

Owen, L., Derbyshire, E., Richardson, S., Benn, D.I., Evans, D.J.A., Mitchell, W.A., 1996. The quaternary glacial history of the Lahul Himalaya, northern India. J. Quat. Sci. 11, 25-42. doi:http://dx.doi.org/10.1002/(SICI)1099-1417(199601/02)11:1<25: AID-JOS209>3.0.CO;2-K.

Owen, La., Bailey, R.M., Rhodes, E.J., Mitchell, Wa., Coxon, P., 1997. Style and timing of glaciation in the Lahul Himalaya, northern India: a framework for reconstructing late Quaternary palaeoclimatic change in the western Himalayas. J. Quat. Sci. 12, 83-109. doi:http://dx.doi.org/10.1002/(SICI)10991417(199703/04)12:2<83::AID-JQS281>3.0.CO;2-P.

Owen, L.A., Derbyshire, E., Fort, M., 1998. The quaternary glacial history of the Himalaya. J. Quat. Sci. 13, 91-120.

Owen, L., Scott, C.H., Derbyshire, E., 2000. The quaternary glacial history of Nanga Parbat. Quat. Int. 63-79. doi:http://dx.doi.org/10.1016/S1040-6182(99) 00037-3.

Owen, L.A., Gualtieri, L., Finkel, R.C., Caffee, M.W., Benn, D.I., Sharma, M.C., 2001. Cosmogenic radionuclide dating of glacial landforms in the Lahul Himalaya, northern India: Defining the timing of Late Quarternary glaciation. J. Quat. Sci. 16, 555-563. doi:http://dx.doi.org/10.1002/jqs.621.

Owen, L.A., Finkel, R.C., Caffee, M.W., 2002a. A note on the extent of glaciation throughout the Himalaya during the global Last Glacial Maximum. Quat. Sci. Rev. 21, 147-157. doi:http://dx.doi.org/10.1016/S0277-3791(01) 00104-4.

Owen, L.A., Kamp, U., Spencer, J.Q., Haserodt, K., 2002b. Timing and style of Late Quaternary glaciation in the eastern Hindu Kush, Chitral, northern Pakistan: A review and revision of the glacial chronology based on new optically stimulated luminescence dating. Quat. Int. 97-98, 41-55. doi:http://dx.doi.org/10.1016/ S1040-6182(02)00050-2.

Owen, L.A., Finkel, R.C., Barnard, P.L., Haizhou, M., Asahi, K., Caffee, M.W., Derbyshire, E., 2005. Climatic and topographic controls on the style and timing of Late Quaternary glaciation throughout Tibet and the Himalaya defined by $10 \mathrm{Be}$ cosmogenic radionuclide surface exposure dating. Quat. Sci. Rev. 24, 1391-1411. doi:http://dx.doi.org/10.1016/j. quascirev.2004.10.014.

Phartiyal, B., Sharma, A., Srivastava, P., Ray, Y., 2009. Chronology of relict lake deposits in the Spiti River, NW Trans Himalaya : Implications to Late Pleistocene - Holocene climate-tectonic perturbations. Geomorphology 108, 264-272. doi: http://dx.doi.org/10.1016/j.geomorph.2009.02.018.

Reimer, P., 2013. Selection and Treatment of Data for Radiocarbon Calibration: An Update to the International Calibration (IntCal) Criteria. Radiocarbon 55, 19231945. doi:http://dx.doi.org/10.2458/azu_js_rc.55.16955.

Reimer, P.J., Brown, T.A., Reimer, R.W., 2004. Discussion: reporting and calibration of post-bomb 14C data. Radiocarbon 46, 1299-1304. doi:http://dx.doi.org/ $10.2458 /$ azu_js_rc.46.4183.

Reimer, P., Hoper, S., Mcdonald, J., Reimer, R., Svyatko, S., Thompson, M., 2015. The Queen's University, Belfast Laboratory Protocols Used fro AMS Radiocarbon Dating at the 14 Chrono Centre Scientific Dating Report. Sci. Dating Rep. Copyr. English Herit. 5.

Richards, B.W.M., Benn, D.I., Owen, L.A., Rhodes, E.J., Spencer, J.Q., 2000. Timing of late quaternary glaciations South of Mount Everestin the Khumbu Himal, Nepal. Bull. Geol. Soc. Am. 112, 1621-1632. doi:http://dx.doi.org/10.1130/0016-7606 (2000) $112<1621$ :TOLQGS $>2.0$. CO; 2

Richardson, Shaun, Reynolds, J.M., 2000. An overview of glacial hazards in the Himalayas. Quat. Int. 65/66, 31-47. doi:http://dx.doi.org/10.1016/S1040-6182 (99)00035-X.

Ringrose, S., Chipanshi, A.C., Matheson, W., Chanda, R., Motoma, L., Magole, I. Jellema, A., 2002. Climate- and human-induced woody vegetation changes in Botswana and their implications for human adaptation. Environ. Manage. doi: http://dx.doi.org/10.1007/s00267-002-2486-0.

Rowan, A.V., 2016. The' Little Ice Age in the Himalaya: a review of glacier advance driven by Northern Hemisphere temperature change. Holocene 0959683616658530 doi:http://dx.doi.org/10.1177/0959683616658530.

Saini, R., 2012. Climate Change \& Glacier Dynamics in Lahaul Himalayas Present and Palaeo Glacial Fluctuations of Lahaul Himalaya, i. ed. Lap Lambert Academic Publishing.

Sanwal, J., Kotlia, B.S., Rajendran, C., Ahmad, S.M., Rajendran, K., Sandiford, M., 2013. Climatic variability in Central Indian Himalaya during the last $\sim 1800$ years: evidence from a high resolution speleothem record. Quat. Int. 304, 183-192. doi: http://dx.doi.org/10.1016/j.quaint.2013.03.029.

Sharma, M.C., Owen, L.A., 1996. Quaternary glacial history of NW Garhwal, Central Himalayas. Quat. Sci. Rev. doi:http://dx.doi.org/10.1016/0277-3791 (95)00061-5

Singh, J., Yadav, R.R., 2005. Spring precipitation variations over the western Himalaya, India, since A.D. 1731 as deduced from tree rings. J. Geophys. Res. D Atmos 110, 1-8. doi:http://dx.doi.org/10.1029/2004JD004855.

Sinha, A., Berkelhammer, M., Stott, L., Mudelsee, M., Cheng, H., Biswas, J., 2011. The leading mode of Indian Summer Monsoon precipitation variability during the last millennium. Geophys. Res. Lett. 38, 2-6. doi:http://dx.doi.org/10.1029/ 2011 GL047713.

Solomina, O.N., Bradley, R.S., Jomelli, V., Geirsdottir, A., Kaufman, D.S., Koch, J., McKay, N.P., Masiokas, M., Miller, G., Nesje, A., Nicolussi, K., Owen, L.A., Putnam, A.E., Wanner, H., Wiles, G., Yang, B., 2016. Glacier fluctuations during the past 2000 years. Quat. Sci. Rev. 149, 61-90. doi:http://dx.doi.org/10.1016/j. quascirev.2016.04.008.

Spencer, J.Q., Owen, L.A., 2004. Optically stimulated luminescence dating of Late Quaternary glaciogenic sediments in the upper Hunza valley: Validating the timing of glaciation and assessing dating methods. Quat. Sci. Rev. 23, 175-191. doi:http://dx.doi.org/10.1016/S0277-3791(03) 00220-8.

Srivastava, P., Kumar, A., Mishra, A., Meena, N.K., Tripathi, J.K., Sundriyal, Y.P., Agnihotri, R., Gupta, A.K., 2013. Early Holocene monsoonal fl uctuations in the Garhwal higher Himalaya as inferred from multi-proxy data from the Malari paleolake. Quat. Proc. 80, 447-458.

Stuiver, M., Polach, H.A., 1977. Reporting of 14C data. Radiocarbon 19, 355-363. doi: http://dx.doi.org/10.1016/j.forsciint.2010.11.013.

Taylor, P.J., Mitchell, W.A., 2000. The Quaternary glacial history of the Zanskar Range, north-west Indian Himalaya. Quat. Int. 81-99. doi:http://dx.doi.org/ 10.1016/S1040-6182(99)00038-5.

Wunnemann, Bernd, Demske, Dieter, Tarasov, Pavel, Kotlia, B.S., Reinhardt, C., Bloemendal, J.D., Hartmann, Kai, Krois, Joachim, Riedel, Frank, Arya, N., 2010. Hydrological evolution during the last $15 \mathrm{Kyr}$ in the Tso Kar Lake Basin (Ladakh, India), derived from geomorphological .... Quat. Sci. Rev. XXX,1-18. doi: http://dx.doi.org/10.1016/j.quascirev.2010.02.017. 
Xu, X., Yi, C., 2014. Little Ice Age on the Tibetan Plateau and its bordering mountains: evidence from moraine chronologies. Glob. Planet. Change 116, 41-53. doi: http://dx.doi.org/10.1016/j.gloplacha.2014.02.003.

Yadav, R.R., 2011a. Tree ring evidence of a 20th century precipitation surge in the monsoon shadow zone of the western Himalaya, India. J. Geophys. Res. 116, $1-$ 10. doi:http://dx.doi.org/10.1029/2010JD014647.

Yadav, R.R., 2011b. Long-term hydroclimatic variability in monsoon shadow zone of western Himalaya, India. Clim. Dyn. 36, 1453-1462. doi:http://dx.doi.org/ 10.1007/s00382-010-0800-8.

Yadav, R.R., Bhutiyani, M.R., 2013. Tree-ring-based snowfall record for cold arid western Himalaya, India since A.D. 1460. J. Geophys. Res. Atmos. 118, 7516-7522. doi:http://dx.doi.org/10.1002/jgrd.50583.
Yadav, R.R., Braeuning, A., Singh, J., 2011. Tree ring inferred summer temperature variations over the last millennium in western Himalaya, India. Clim. Dyn. doi http://dx.doi.org/10.1007/s00382-009-0719-0.

Yadava, A.K., Braeuning, A., Singh, J., Yadav, R.R., 2016. Boreal spring precipitation variability in the cold arid western Himalaya during the last millennium, regional linkages, and socio-economic implications. Quat. Sci. Rev. 144, 28-43. doi:http://dx.doi.org/10.1016/j.quascirev.2016.05.008.

Zhang, David D., Li, S.H., 2002. Optical dating of Tibetan human hand- and footprints: An implication for the palaeoenvironment of the last glaciation of the Tibetan Plateau. Geophys. Res. Lett. 29, 3-5. doi:http://dx.doi.org/10.1029/ 2001 GL013749. 